\title{
Serum neurofilament light chain in relapsing-remitting $\mathrm{MS}$
} Unchaining disease activity prediction?

Ruth Ann Marrie, MD, $\mathrm{PhD}$

Correspondence to Dr. Marrie:

rmarrie@hsc.mb.ca

Neurol Neuroimmunol Neuroinflamm 2018;5:e421; doi: 10.1212/ NXI.0000000000000421

\section{See Article}

MS is a chronic disease of the CNS, well recognized for its diverse clinical presentations and outcomes. Clinicians continue to struggle to predict short- or long-term prognosis of persons affected by MS, to predict response to the growing array of diseasemodifying treatments available, and to identify persons at risk of serious adverse events from those treatments. As such, valid, reliable, and objectively assessed biologic measures, that is, biomarkers, which can aid clinicians in predicting these outcomes, are sorely needed. ${ }^{1}$

Neurofilaments are key components of the neuronal cytoskeleton. They provide structural support to axons, and elevated levels of these proteins have been observed in several neurodegenerative diseases including MS. Chitinases are glycosyl hydrolases; chitinase 3-like 1 (CHI3L1) lacks chitinolytic activity and is expressed by microglia, macrophages, and astrocytes. ${ }^{2}$ In CIS, higher CSF levels of CHI3L1 are associated with shorter time to diagnosis of MS. ${ }^{2}$ Elevated CSF levels of neurofilament light chain (NF-L) have been associated with brain atrophy, ${ }^{3}$ and a recent longitudinal study of 41 persons with clinically isolated syndrome (CIS) or relapsing-remitting MS (RRMS) found that NF-L levels in CSF correctly classified $85 \%$ of participants with respect to disease activity over 2 years. ${ }^{4}$

In this issue of Neurology ${ }^{\circledR}$ Neuroimmunology \& Neuroinflammation, Varhaug et al. ${ }^{5}$ sought to determine whether serum NF-L and CHI3L1 predict disease activity in RRMS. The study population included 85 participants in a randomized, doubleblind controlled trial in which they were randomized to supplement with omega-3 fatty acids or placebo conducted over 6 months, with the addition of interferon-beta-1a subcutaneously 3 times weekly for the subsequent 18 months. Serum samples were drawn at baseline and months 3, 6, 12, and 24. Using these samples, the authors measured CHI3L1 concentrations using an ELISA and NF-L concentrations using a single-molecule array assay. They found that CHI3L1 levels were not associated with relapses, disability, or MRI measures of disease activity. By contrast, NF-L levels were associated with MRI measures. After accounting for age at enrollment, sex, and follow-up time, median (interquartile range) NF-L levels were higher in participants with new gadolinium-enhancing lesions (37.4 [25.9-52.4] pg/ $\mathrm{mL})$ than among those without such lesions (28.0 [21.9-36.4] pg/mL, $p<0.001)$ and higher among participants with new T2 lesions (37.3 [25.1-48.5] $\mathrm{pg} / \mathrm{mL}$ ) than among those without new T2 lesions (27.7 [21.8-35.1] pg/mL, $p<0.001)$. Despite the association of NF-L levels with MRI measures of disease activity, NF-L levels were not associated with relapses or disability progression. NF-L levels dropped after the initiation of interferon-beta-1a therapy, but the association of NF-L levels with MRI measures did not differ before or after the initiation of therapy. The observed decline in serum NF-L levels after the introduction of interferon-beta-1a therapy is consistent with observations in other cohorts that CSF NF$\mathrm{L}$ levels declined after the introduction of natalizumab and fingolimod. ${ }^{6,7}$ Within individuals, a 10-pg/ $\mathrm{mL}$ increase in NF-L levels was associated with $48 \%$ increased odds of new gadolinium-enhancing lesions (OR, 1.48; 95\% CI, 1.15-1.90) and 62\% increased odds of a new T2 lesion (OR, 1.62; 95\% CI, 1.222.15).

Strengths of the study include the prospective, longitudinal design, capture of clinically relevant outcomes including relapses and disability, and the use of mixed models, which allowed the identification of associations of NF-L levels with outcomes at the individual level. However, relevant limitations should be considered. All participants had RRMS; the average disease duration was short (1.0 years); and median disability was mild (Expanded Disability Status Scale score 2), and it is unknown whether these findings would generalize to individuals with longer disease duration or more severe disability. The study cohort was modest in size; only $23(27.1 \%)$ participants experienced a relapse over the study period, and only

From the Departments of Internal Medicine and Community Health Sciences, University of Manitoba, Winnipeg, Canada.

Funding information and disclosures are provided at the end of the editorial. Go to Neurology.org/nn for full disclosure forms.

This is an open access article distributed under the terms of the Creative Commons Attribution-NonCommercial-NoDerivatives License 4.0 (CC BY-NC-ND), which permits downloading and sharing the work provided it is properly cited. The work cannot be changed in any way or used commercially without permission from the journal. 
$26(30.5 \%)$ participants experienced disability progression, reducing the power to detect associations of serum NF-L levels with these outcomes. The magnitude of the effects observed was also small.

The authors suggest that serum NF-L may become a clinically useful biomarker for "detecting subclinical MRI activity and treatment response" in RRMS. Certainly, a serum NF-L measure is more practical for clinical purposes than a CSF measure. The ability to substitute a serum measure that could be assessed repeatedly for less frequent, less convenient, and more costly MRIs would be welcome. However, considerably more work is needed for serum NF-L levels to be appropriate for use in practice. We need to establish that the associations reported apply to other MS populations, which differ with respect to their demographic (age, sex, and race) and clinical (disability, disease duration, clinical course, and comorbidities) characteristics and that the magnitude and direction of these associations are consistent. We also need to determine whether a $10-\mathrm{pg} / \mathrm{mL}$ change in NF-L levels for an individual with MS reproducibly indicates subclinical disease activity with adequate sensitivity and specificity, and whether reductions in those levels indicate resolution of activity for that individual. The lack of association between NF-L levels and clinical disease activity also needs to be addressed, hopefully by the use of larger cohorts.

Serum NF-L levels deserve continued evaluation as a biomarker of disease activity. However, several large, prospective cohort studies with comprehensively characterized and heterogeneous participants followed over longer periods are needed to deter- mine whether it should be adopted in clinical practice.

\section{STUDY FUNDING}

No targeted funding reported.

\section{DISCLOSURE}

Ruth Ann Marrie serves on the editorial board of Neurology and Multiple Sclerosis Journal; receives research funding from the Canadian Institutes of Health Research (CIHR), Research Manitoba, Multiple Sclerosis Society of Canada, Multiple Sclerosis Scientific Foundation, National Multiple Sclerosis Society, Crohn's and Colitis Canada, Rx\&D Health Research Foundation, and Waugh Family Chair in Multiple Sclerosis; and has conducted clinical trials funded by Sanofi-Aventis. Go to Neurology. org/nn for full disclosure forms.

\section{REFERENCES}

1. El Ayoubi NK, Khoury SJ. Blood biomarkers as outcome measures in inflammatory neurologic diseases. Neurotherapeutics 2017;14:135-147.

2. Cantó E, Tintoré M, Villar LM, et al. Chitinase 3-like 1: prognostic biomarker in clinically isolated syndromes. Brain 2015;138:918-931.

3. Petzold A, Steenwijk MD, Eikelenboom JM, Wattjes MP, Uitdehaag BM. Elevated CSF neurofilament proteins predict brain atrophy: a 15-year follow-up study. Mult Scler 2016;22:1154-1162.

4. Håkansson I, Tisell A, Cassel P, et al. Neurofilament light chain in cerebrospinal fluid and prediction of disease activity in clinically isolated syndrome and relapsing-remitting multiple sclerosis. Eur J Neurol 2017;24:703-712.

5. Varhaug KN, Barro C, Bjornevik K, et al. Neurofilament light chain predicts disease activity in relapsing remitting multiple sclerosis. Neurol Neuroimmunol Neuroinflamm 2017;5:e422. doi: 10.1212/NXI.0000000000000422.

6. Kuhle J, Disanto G, Lorscheider J, et al. Fingolimod and CSF neurofilament light chain levels in relapsing-remitting multiple sclerosis. Neurology 2015;84:1639-1643.

7. Gunnarsson M, Malmestrom C, Axelsson M, et al. Axonal damage in relapsing multiple sclerosis is markedly reduced by natalizumab. Ann Neurol 2011;69:83-89. 


\title{
Neurology \\ Neuroimmunology \& Neuroinflammation
}

\author{
Serum neurofilament light chain in relapsing-remitting MS: Unchaining disease \\ activity prediction? \\ Ruth Ann Marrie \\ Neurol Neuroimmunol Neuroinflamm 2018;5; \\ DOI 10.1212/NXI.0000000000000421
}

This information is current as of November 29, 2017

\begin{abstract}
Updated Information \&
including high resolution figures, can be found at:

Services

http://nn.neurology.org/content/5/1/e421.full.html

References

This article cites 7 articles, 0 of which you can access for free at: http://nn.neurology.org/content/5/1/e421.full.html\#\#ref-list-1

Permissions \& Licensing

Information about reproducing this article in parts (figures,tables) or in its entirety can be found online at:

http://nn.neurology.org/misc/about.xhtml\#permissions

Reprints

Information about ordering reprints can be found online: http://nn.neurology.org/misc/addir.xhtml\#reprintsus
\end{abstract}

Neurol Neuroimmunol Neuroinflamm is an official journal of the American Academy of Neurology.

Published since April 2014, it is an open-access, online-only, continuous publication journal. Copyright

Copyright $\odot 2017$ The Author(s). Published by Wolters Kluwer Health, Inc. on behalf of the American

Academy of Neurology.. All rights reserved. Online ISSN: 2332-7812.

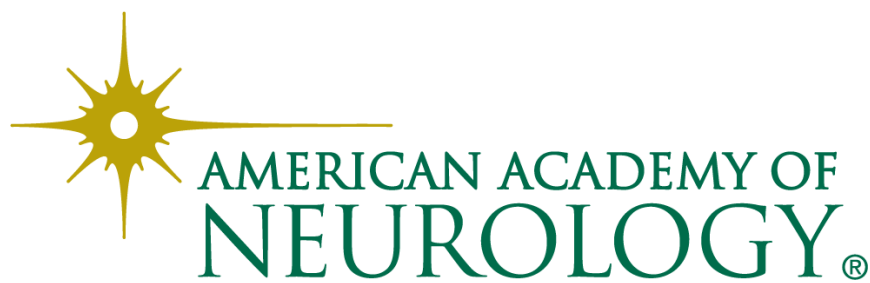

